\title{
ECONOMY AND FORECAST FOR 2020: 3 KEY TRENDS IN THE FUTURE
}

\author{
Bohumír Stedron ${ }^{1}$, Helena Bínová \\ ${ }^{I}$ Ass. Prof, Charles University Prague Faculty, FTVS, Jose Martiho 31, 16252 Praha 6 \& Technical University \\ Prague Faculty of Transportation Sciences, Department of Logistics and Management of Transport, Konviktská 20, \\ Prague 1, 110 00, Czech Republic \\ ${ }^{2}$ Technical University Prague Faculty of Transportation Sciences, Department of Logistics and Management of \\ Transport, Konviktská 20,Prague 1, 110 00, Czech Republic
}

\begin{abstract}
The article deals with 3 key trends in the future and their general implications including 3D, RFID, Business Intelligence and new managerial positions.

$3 D$ by 2020 could replace conventional mass-production. The basic trends in the RFID aplications will be: RFID Wearables, RFID On Merchandise, Host Card Emulation (HCE) Payment Solutions, Printed RFID Technology, RFID chip tracking everyone everywhere in the near future. Business intelligence will be transformed to the general intelligence.The contribution covers the the following topics: selected Aspects of economy and social Aspects of Information Systems, complex technological and human Issues in today's globalized and interconnected World and presents new results in the diffused way.
\end{abstract}

Key words: 3 Key trends, 3D, RFID, Business Intelligence, Computer Feudal Monarchy, New Managerial Positions

JEL Classification: A10, A11, A19, E27, E69

\section{INTRODUCTION}

There are many predictions, regarding the future [1], [2], [3],[4],[10], [12] and all may seem like science fiction, but as the great scientist Arthur C Clarke said: "Any sufficiently advanced technology is indistinguishable from magic." Profiles of The Future, 1961 (Clarke's third law).

The publication of the National Intelligence Council „Global Trends 2030 Alternative Worlds"[4] deals with 4 Megatrends:

- Individual empowerment will accelerate owing to poverty reduction, growth of the global middle class, greater educational attainment, widespread use of new communications and manufacturing technologies, and health-care advances.

- Diffusion of Power: There will not be any hegemonic power. Power will shift to networks and coalitions in a multipolar world.

- The demographic arc of instability will narrow. Economic growth might decline in "aging" countries. Sixty percent of the world's population will live in urbanized areas; migration will increase [1].

- Demand for these resources will grow substantially owing to an increase in the global population. Tackling problems pertaining to one commodity will be linked to supply and demand for the others [2].

\section{OCCAM'S RAZOR}

Occam's razor is a problem-solving principle devised by William of Ockham (c. 1287-1347), who was an English Franciscan friar and scholastic philosopher and theologian. The principle states that among competing hypotheses, the one with the fewest assumptions should be selected.

In science, Occam's razor is used as a heuristic (discovery tool) to guide scientists in the development of theoretical models rather than as an arbiter between published models. In the scientific method, Occam's razor is not considered an irrefutable principle of logic or a scientific result; the preference for simplicity in the scientific method is based on the falsifiability criterion.

For each accepted explanation of a phenomenon, there is always an infinite number of possible and more complex alternatives.

\section{KEY TRENDS FOR THE ECONOMY AND MANAGEMENT UNTIL 2020}

Using Occam's razor, we can identify 3 Key Trends:

\subsection{D}

Development of the society will be affected significantly by the $3 \mathrm{D}$ printing. It will mean the extreme decentralization of production and also manufacturing in the customer's location. 
3D printing is a process of production of three-dimensional objects from suitable material through specific devices. Printing successively layer by layer is under computer's control.

3D printing technology beginnings appeared in the second half of the 20th century. In March 1986, Charles Hull patented a technology called stereolithography - a method that uses ultraviolet laser beam. Surface of polymer liquid, wherein it draws the individual layers of the object. Then, the layer is cured by UV light. At the end of 90's, Charles Hull started the company 3D Systems and created the first device that was able to print three-dimensional object - SLA device, or "stereolithography apparatus".

The SLA models have served to the public and became the basis for the development of today's 3D printers. After 2003, when the development of technology accelerated due to expiration of some patents, there are new technologies, terminology and materials, but for clarity they are more often called simply "3D printing". The material is applied from the nozzles on a moving platform. Patterned layers create a 3D object. Printing technology of physical 3D objects from digital data is called "additive manufacturing".

Areas of use of 3D printing technology:

- Medicine and Research

- Food Industry

- Consumer products

- Design, architecture, electrical engineering, mechanical engineering

- Education

- Automotive and aerospace industry

- Arms industry

\subsubsection{Medicine and Research}

- $\quad$ Prosthetics and assistive devices

In 2013, an Englishman Paul McCarthy printed to his son a robotic prosthesis at home $3 \mathrm{D}$ printer. To do this, a guide that he found on the internet was enough for him. His son was born without fingers on one hand, and thanks to printed mechanical prosthesis could grasp various objects for the first time.

This has dramatically improved his quality of life. Price of such produced prostheses McCarthy enumerated for a couple dollars.

- $\quad$ Hearing Aids

According to estimations by the British analyst Phil Reeves currently it is over 10 million printed hearing aids in the world.

- $\quad$ Burns and skin injuries

In the treatment of skin injuries with $3 \mathrm{D}$ printing the situation is still in the stages of development and testing. Currently, scientists are investigating the possibility of combining technology of the 3D printing and technology of growing stem cells. It is intended to use it also in medical cosmetics.
- $\quad$ Fractures and bone destruction

In mid-2013 it was possible to replace $75 \%$ of the US patient's skull thanks to a special 3D compensation. Special polymer implant titled Osteofab was designed to promote the growth of tissues and for faster recovery of the patient.

- Human organs

In connection with printing organs the mostly spoken is the company Organovo which has developed the technology to print small samples of human liver tissue. Samples were able to survive a few days. However it is still possible to print the organs only in shape, but not functionally correct.

\subsubsection{Food Industry}

Information about 3D printing of food spread in the middle of this year, mainly thanks to the American space agency NASA. The agency thumbed-up for a research program to print food in space.

The idea that astronauts in space will print pizza is tempting, but inaccurate.

The NASA Program is based on the replication characteristics of food. It is about to allow a 3D printer printing from such materials, which will contain enough calories and organic molecules as similar as possible to those in the classic food.

According to the experts the cartridge for printing of food would include, for example, powder from insects, algae or milk. Each cartridge would fit to some taste and at the same time would be nutritionally balanced. The project of the food printer is still in the development stage.

The 3D printing is already used in the food industry, but only for special techniques - it is possible to print from material such as chocolate. It is melted by heat in printer's nozzles and cooled again to harden, which is ideal for printing 3D models. In the US there are two architects from San Francisco printing 3D objects from sugar. Sugar designs pieces are printed on common $3 \mathrm{D}$ printer with customization and to harden sugar alcohol is used.

In Barcelona, there is a project that aims to print dishes from dough, paste or from solidifying liquids. These have the perfect consistency for filling food cartridges for printers and it is theoretically possible to prepare from them more complicated, but real food.

\subsubsection{Consumer Products}

Consumer goods will be changed from prefabricated to customized goods.

Here arises the opportunity to design and print your own products for daily consumption. Current experiments are with materials such as:

- White plastic (thermoplastic material ABS (acrylonitrile butadiene styrene)). 
- Ceramics and glazing (ceramic composition of aluminum oxide and silicon oxide, the completed product is after remove from the printer glazing and then hardened, sintered, in fire as well as classic ceramics).

- Wood (a mixture containing about one third of the wood fibers (directly from wood or wood waste from sawing machines dust) and two thirds of PLA material (polylactic acid).

- $\quad$ Metal (electrical components).

- Textiles (materials for printing on thread and fabrics.

There has been already lingerie printed from the latexrubber polymers enriched by cotton fibers. Other materials enriched by viscose are also tested).

\subsection{Phenomenon RFID}

Forecast can stem from a wide-scale monitoring of the RFID technology [10], [11]. Forecast created with exponential regression until 2021 is shown in Table 1.

Table -1: Total number of purchased RFID tags and the number of locations of their deployment

\begin{tabular}{||l||l|l|l|l||}
\hline & 2009 & 2011 & 2013 & 2015 \\
\hline \hline $\begin{array}{l}\text { Total } \\
\text { purchased tags } \\
\text { (in mil.) }\end{array}$ & 346 & 2070 & 4780 & 9800 \\
\hline $\begin{array}{l}\text { Total locations } \\
\text { with RFID } \\
\text { reader }\end{array}$ & 6600 & 19500 & 45600 & 70500 \\
\hline $\begin{array}{l}\text { Total number } \\
\text { or RFID } \\
\text { readers }\end{array}$ & 18300 & $\begin{array}{l}135 \\
100\end{array}$ & $\begin{array}{l}261 \\
600\end{array}$ & 577500 \\
\hline
\end{tabular}

\begin{tabular}{||l||l|l|l||}
\hline \hline & 2017 & 2019 & 2021 \\
\hline \hline $\begin{array}{l}\text { Total } \\
\text { purchased tags } \\
\text { (in mil.) }\end{array}$ & 21700 & 38500 & 75500 \\
\hline $\begin{array}{l}\text { Total locations } \\
\text { with RFID } \\
\text { reader }\end{array}$ & 138000 & 225000 & 394000 \\
\hline $\begin{array}{l}\text { Total number } \\
\text { or RFID } \\
\text { readers }\end{array}$ & 1125500 & 2465500 & 5458000 \\
\hline
\end{tabular}

Source: author

More than 260000 RFID readers will be used in 2013, which will be deployed in 45000 locations over Europe. In the same year, RFID readers will process 4.7 billion tags.

These numbers will grow significantly until 2021 when more than 5 million readers in 394000 locations are expected to process more than 75 billion tags (see Graphs 1$3)$.

Graphs 3-5 are created using exponential regression.
Exponential regression has 2 parametres generally:

$$
\begin{aligned}
y_{i}=b_{0} e^{x_{i} b_{1}} & \\
\ln \left(y_{i}\right)= & \ln \left(b_{0} e^{x_{i} b_{1}}\right) \\
& \ln \left(y_{i}\right)=\ln \left(b_{0}\right)+\ln \left(e^{x_{i} b_{1}}\right) \\
& \ln \left(y_{i}\right)=\ln \left(b_{0}\right)+x_{i} b_{1}
\end{aligned}
$$

where $e=2,71828 \ldots$ is the basis of natural logarithm. The formula of the exponential regression for chart on Fig. 4 is:

$$
y=36,396 e^{0,3687 x}
$$

where $x$ represents years on the time axis.

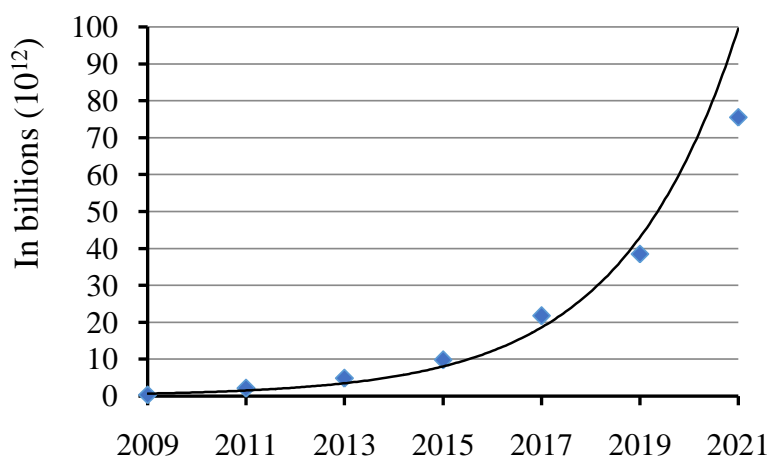

Chart 1: Total numbers of purchased tags per year (in billions, i. e. $10^{12}$ ) (blue points). Full line is exponential trend. Source: authors.

The formula of the exponential regression for chart on Fig. 5 is:

$$
y=691,31 e^{0,3067 x}(1.6)
$$

where $x$ represents years on the time axis.

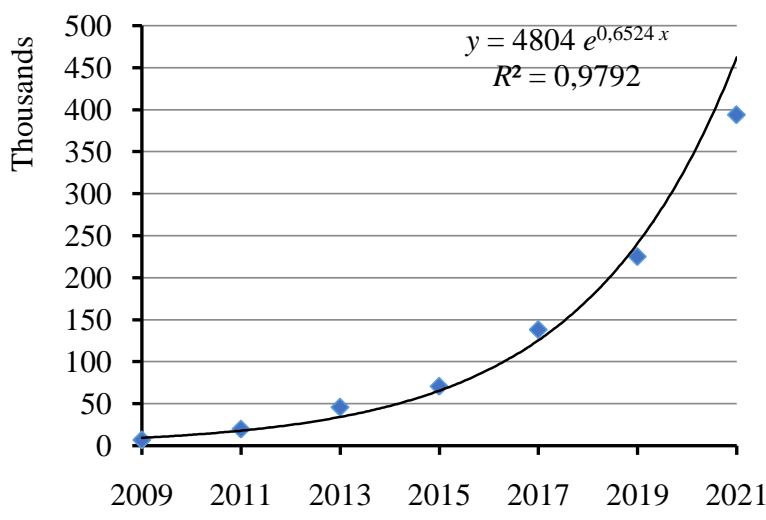

Chart 2: Total numbers of locations with RFID reader in thousands (blue points). Full line is exponential trend.

Source: authors. 
The formula of the exponential regression for chart on Fig. 6 is:

$$
y=2491,31 e^{0,3632 x}
$$

where $x$ represents years on the time axis.

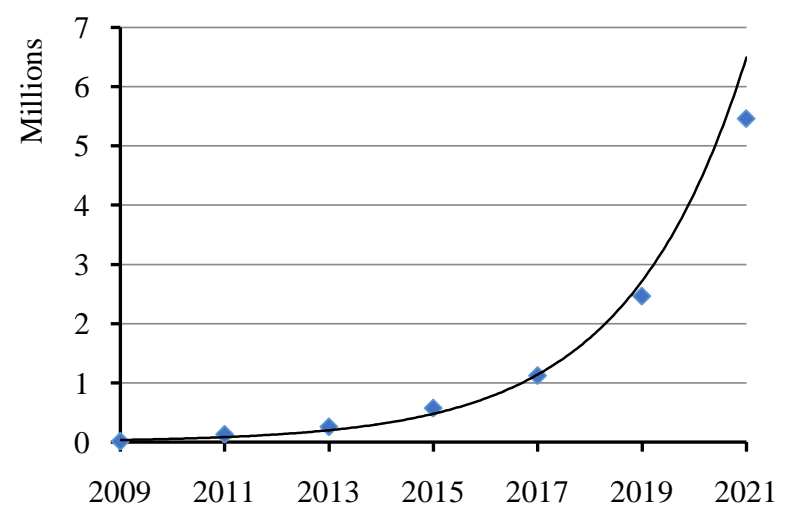

Chart 3: Total numbers of RFID readers (blue points) in millions. Full line is exponential trend. Source: authors.

The values in the table 3 represent only a small percentage of the total number of objects which can be tagged. The forecast based on the prediction of the BRIDGE project says that only $2 \%$ of all FMCG (fast moving consumer goods) will be tagged in 2013 .

Further, it presumes that roughly $25 \%$ of non-food and $5 \%$ of food retail items will be tagged by 2021. If the technology development is confirmed in following years, the price of RFID tags could drop below one eurocent [12] which could lead to a dramatic rise in the number of tags especially the number of tags in the food-processing industry could shoot up to hundreds of billions.

The RFID technology represents the most important economic factor of the near future. The price of RFID passive tags will further decrease thanks to mass production and technology development, it is predicted that between 2012 and 2013 the price of one tag will drop to 5 USD cents and in 2015 these could be made under the price of 3 cents. The price development is shown on graph 4 .

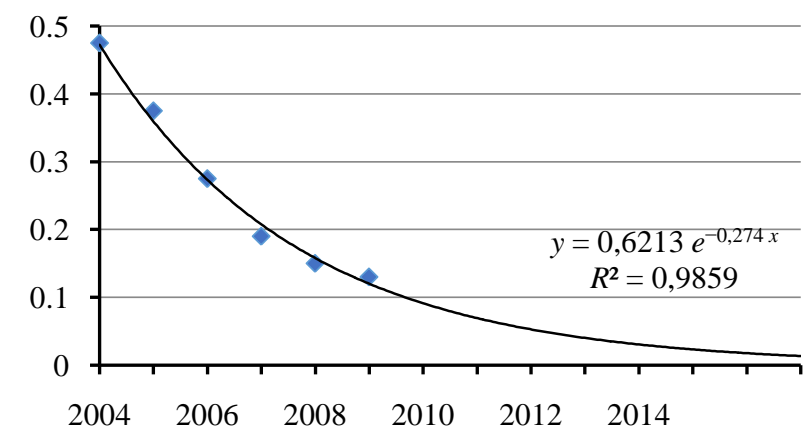

Chart 4: Development of passive RFID tags price. Blue points - historic prices; full line - compensation and exponential extrapolation. Source: author [11].
In the future, the price of RFID will be only fractions of cents with the size smaller than a pollen grain. This, in connection with distributed artificial intelligence, it will enable:

- fix every human to the megaintegrated computer system and monitor his health, social position and political views and the computer feudal monarchy will be established effective central planning of the whole world economy

- $\quad$ electronic communication with pets, later also with mammals, cetaceans and vegetation, i.e. whole biosphere which will become a new segment of economy and after change of legislation will be integrated into the political and economic system.

\subsection{Business Intelligence}

According to recent studies and analysis, the global market for Business Intelligence (BI) software and services is likely to double over the 4 year period between 2012 and 2016, reaching approximately $\$ 143$ billion in total.

Based on the data from the official annual reports of the 4 largest BI vendors - Microsoft, IBM, Oracle and SAP from 1992 to 2013, we can assess their performances over the last 20 years, and then estimate what trend their annual revenues are most likely going to follow until 2020.

Microsoft Corporation has been doing fairly well since 1992, following almost linear trend with slightly steeper growth during the period 2007-2009. This stable growth might continue with the same trend, reaching annual revenue worth $\$ 100$ billion by 2020 .

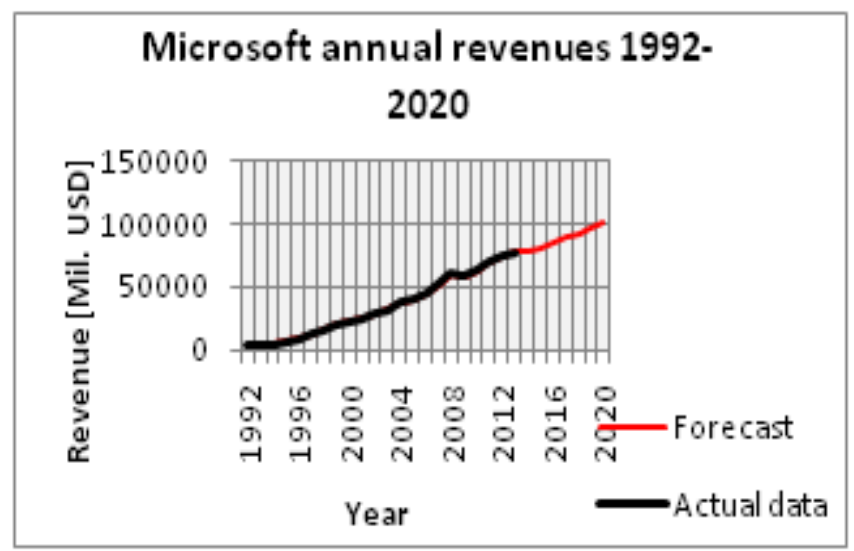

Chart -5: Microsoft annual revenues 1992-2020. Source: author. Data source: Microsoft Annual Reports.

International Business Machines (IBM). Thanks to much longer market activity (IBM mark founded in 1924), the annual revenues of IBM started at $\$ 65$ billion for the year 1992 , then growing more gradually than in case of the other vendors. Despite its many deviations, the progress is almost linear, and so is the forecasted trend. With all aspects going well, IBM's revenue for the year 2020 could be worth $\$ 120$ billion, increasing the current one by $\$ 20$ billion (the same as Microsoft). 


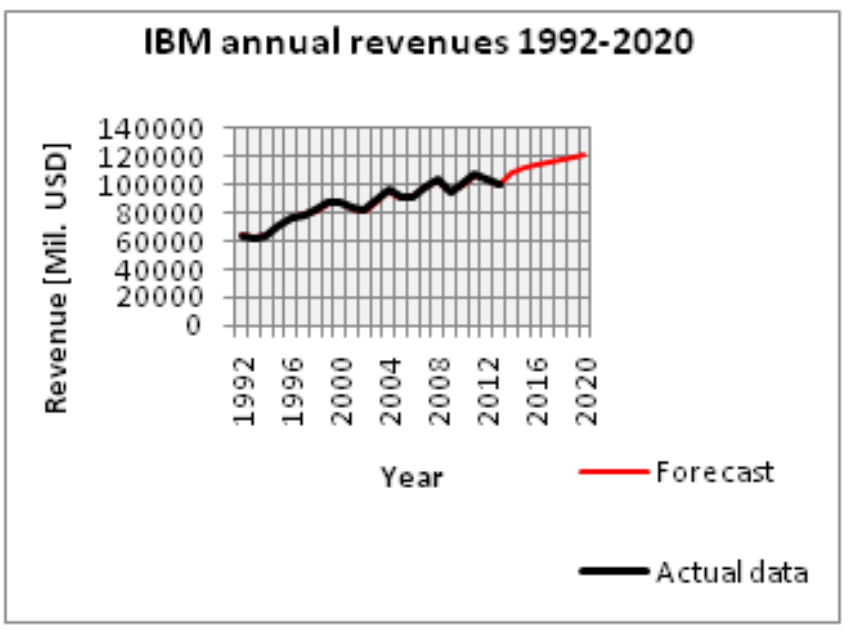

Chart -6: IBM annual revenues 1992-2020. Source: author. Data source: Data source: IBM Annual Reports

Oracle Corporation. In case of Oracle, the youngest one of these 4 leaders, we can clearly see a bit more dynamic progress. Starting with linearity, the trend of Oracle's annual revenues changed to something similar to hyperbolic tangent in 2001. A mild decrease from 2001 has been followed by an almost exponential growth, slowing down again in 2011. To be optimistic enough, we can conclude that the trend is going to be linear again in the following period, possibly exceeding \$40 billion of annual revenue in 2020.

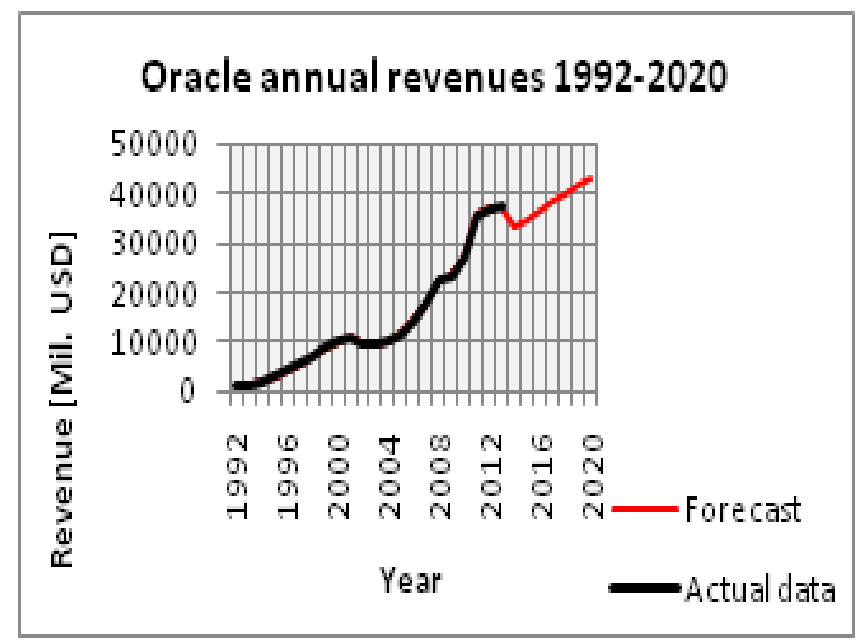

Chart -7: Oracle annual revenues 1992-2020. Source: author. Data source: Data source: Oracle Annual Reports.

SAP, the only European leader of BI platforms production, had considerably lower revenues than its other competitors. However, it possesses ca. quarter of the ERP and CRM software market, which probably reflected in a steeper growth from 2009 on. Based on these facts and overall data, the trend is most likely to remain linear and can lead to 2020 annual revenue worth $€ 20$ billion ( $\sim 28$ billion).

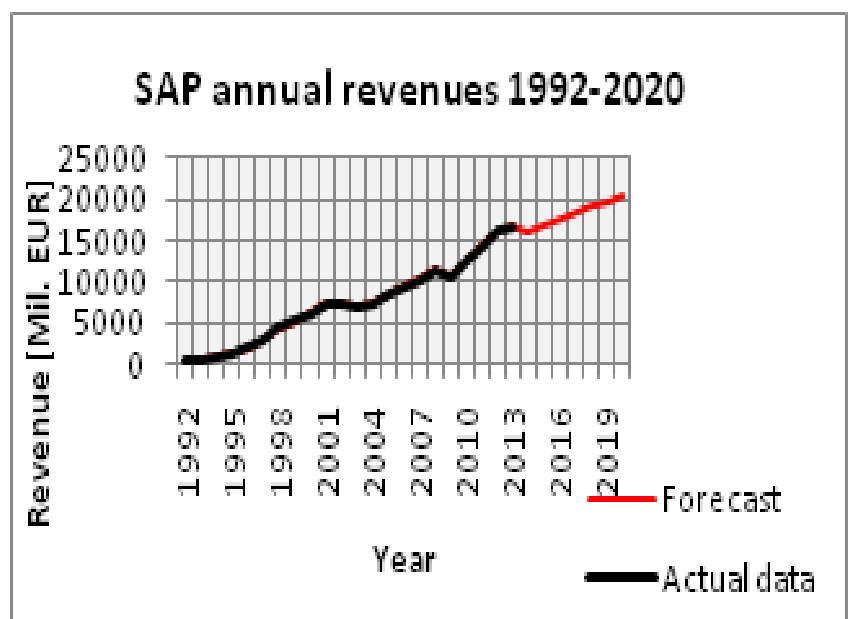

Chart -8: SAP annual revenues 1992-2020. Source: author. Data source: Data source: SAP Annual Reports.

All this facts shows, that the applications of BI will be growing and transformation of the BI to the general intelligence may be predicted. In conclusion, after summary of the above results, it becomes clear that artificial intelligence will not be ,all-knowing“ and ,all-wise“, but only ,cleverer to a limited extent" than a human being.

\section{CONCLUSION}

More than 10000 years ago the 3 Key trends were: fire, processing of Metals and developing of the agriculture. Today is the situation different: the Key Trends will be 3D printing, RFID everywhere and Business Intelligence.

For some time now, the General Intelligence community has been trying to imitate intelligent behavior with computer programs. This is not an easy task because a computer program must be able to do many different things in order to be called intelligent. Instead of looking at a general definition of General (Artificial) Intelligence, one can also restrict oneself to the definition of artificially intelligent systems.

There are many definitions around, but most of them can be classified into the following four categories:

- Systems that think like humans

- Systems that act like humans

- Systems that think rationally

- $\quad$ Systems that act rationally.

The Forecast for the Future will include:

Self-learning management systems, MIS controlled by voice and ideas, are the wave of the future.

With the advent of these technologies, which will be available on the market, MIS will get a whole new dimension. The system cannot only learn many things of one's own accord, it can also execute them, and work closely with the wearer mind maps and react to them. It will also be able to respond to spoken words. Writing queries for this system will be completely replaced by this. 
Year 2020 could look as follows:

- Voice as the main controller of all systems

- MIS will use extensively systems working with the human mind - with feelings

- Self-learning systems will handle unknown data arbitrarily without any pattern on the basis of matching

- A common perception of augmented reality

- 3D holographic display

- Devices will perceive the space around us

- Devices thin as paper

- Display area anywhere, anytime

- Top level wireless online communication

- $\quad 99 \%$ of the information will be stored in the cloud

- IBM achieved turnover of 120 billion of dollars

- Microsoft reaches a turnover of 140 billion of dollars

- SAS Instutute turnover reaches 6 billion of dollars

- Czech companies offering MIS together reach a turnover more than 100 million of dollars

\section{New Cyberspace Managers in the 2020}

Taking into consideration the aforementioned information, it becomes obvious that this development will lead to new managerial positions in the future. Let us briefly introduce some that are likely to appear:

- The Identity Manager will operate in the area of data protection and related legal restrictions. It will be necessary to identify, whether the business part ner is a human being, a robot or a segment of the biosphere. A new scientific discipline related to identity will be developed.

- The Chaos Manager: new inventions like Internet of Things will complicate the whole system. Special programs like neural or genetic software will be essential to specify new gaps in the market.

- E-government manager and Technostress manager and many others...

The future mega-integrated single computer system will be reflected in the political sphere of the next decades by a computer feudal monarchy controlling the entire movement of the society through mobile telephony, RFID and other sophisticated segments of the technosphere.

\section{REFERENCES}

[1]. Bína, L., Bínová, H., Březina, E., Kumpošt, P., Padělek, T. (2014). Comparative Model of Unit Costs of Road and Rail Freight Transport for Selected European Countries. European Journal of Business and Social Sciences, Zurich, ISSN 2235-767X, Volume 3, Issue 04, July 2014, pp. 127136. Avalaible from: http://www.ejbss.com/home.aspx [2]. Bínová, H. (2014). Elbe River Waterway - Economic and Social Benefits.Transactions of the VŠB - Technical University of Ostrava, No. 2, 2014, Vol. 14, řada stavební, pp 93-100, ISSN: 1804-4824 (online); No. 2, 2014, Vol. 14, řada stavební, pp 31-38, ISSN 1213-1962 (print), Civil Engineering Series, doi: 10.2478/tvsb-2014-0016, avalaible from:http://www.degruyter.com/view/j/tvsb,

[3]. http://www.gartner.com/newsroom/id/2637615
[4]. Global trends 2030: Alternative worlds. Avalaible from: http://globaltrends2030.files.wordpress.com/2012/11/globaltrends-2030-november2012.pdf

[5]. Globální trendy 2030. Available from: http://sbp.fsv.cuni.cz/SBP-231-version1-wp_20.pdf

[6]. Jak bude svět vypadat v roce 2030. In: [online]. [cit. 2014-03-02]. Avalaible from: http://zpravy.ihned.cz/c158940930-svet-v-roce-2030-ekonomicky-kolaps-a-boj-ovodu

[7]. Kostrecová, E., Bínová, H. (2015): Security Information and Event Management. PARIPEX - Indian Journal of Research, ISSN 2250-1991, Volume IV, Issue II, February 2015, DOI: 10.15373/22501991, pp.119-120. Avalaible from:

http://theglobaljournals.com/paripex/file.php?val=February_ 2015_1423916887_40.pdf

[8]. Prognóza CIA. In: [online]. [cit. 2014-03-02]. Avalaible from: http://pravdu.cz/cia/prognoza-cia-pro-dalsi-desetileti

[9].http://www.mgmtpress.cz/download/?file=fil_filename $\%$ 2F2b\%2F115.pdf\&downloadFilename $=\mathrm{Ud} \% \mathrm{C} 3 \% \mathrm{~A} 1$ losti+w ww.pdf.

[10].https://www.btplc.com/Innovation/News/timeline/static timeline.pdf

[11]. Štědroň, B. \& Budiš, P. \& Štědroň, B. jr. (2009) Marketing a nová ekonomika. Praha: C.H.BECK

[12]. Štědroň, B. \& Kocour V.: (2014) Technologické prognózy a telekomunikace, Praha: Sdělovací technika

[13]. http://futurerfid.ektf.hu/

[14]. http://www.rfidjournal.com/articles/view?7268

[15]. http://www.rfid-epc.cz/

\section{BIOGRAPHIES}

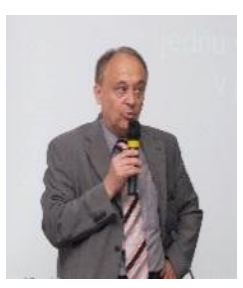

Ass.Prof. RNDr. Bohumír Štědroň, Ph.D., Charles University Prague Faculty, FTVS, 16252 Praha 6 \& Technical University Prague Faculty of Transportation Sciences

Konviktská 20, Prague 1, $110 \quad 00$ stedron@seznam.cz

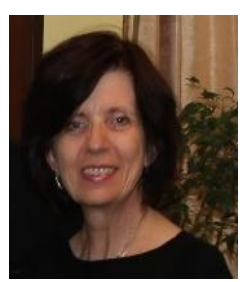

Ing. Helena Bínová, Ph.D. is an university tutor at Czech Technical University Prague, Faculty of Transportation Sciences, Head of the Intermodal Transport and Logistics Laboratory. Konviktská 20, Prague 1, 110 00

binova@fd.cvut.cz 